\title{
女子学生の体力分析
}

運動経験，ローレル指数，体育実技授業による体力変化について一一

中 嶋 英 昭 (和洋女子大学)
永 井 信 雄 (和洋女子大学)
(昭和52年11月22日 受付)

\section{A Study on Physical Fitness of Female Students \\ In Relation to Organized Club Training, Rohrer's Index, Physical Education Activity Classes}

\author{
Hideaki Nakashima* \\ Nobuo Nagai*
}

\begin{abstract}
It is a well known fact that physical fitness is influenced by physical activity. The purpose of this study is to find the relationship of physical fitness to organized club training, obesity, leanness and a weekly physical education program. The subjects were women aged 18 and 19 years, and the total number of participants were 1064.

The results showed that $49 \%$ of the subjects had not been engaged in any training, $25 \%$ have had snch experiences of 6 months up to 2 years, $20 \%$ of them, 2 up to 5 years and $6 \%$ of the total group had 5 years and over of organized club training. This last group was physically fit the most. There were significant differences between the group of 5 years and over of sports training and other three groups. But there was no significant difference in the level of fitness between the group of less than 2 years and group of non-training. The subjects whose Rohrer's indexes were above 160 and below 110 showed inferior in the physical fitness to the normal index group. The subjects had 90 minutes of physical education classes every week and the average heart rate during active 45-minutes among the selected subjects was formed to be $138 \pm$ 15 beats per minute. The classes were thus considered not to be strenuous. Then all the participants were divided into five groups according to their level of physical fitness. All subjects were tested in fitness in April and December. The tests showed there was a significant decline in the physically well conditioned students examined in April, but a significant increase in the physically poorly conditioned students.

In conclusion, the average value of physical fitness of the 1064 participants seemed
\end{abstract}

* Wayo Women's University, Konodai, Ichikawa, Chiba (272) 
to have been lowered by the non-training group, the obese group, and the lean group. The weekly physical education classes were considered to have provided positive effect in physical fitness among the average and the poorly conditioned students.

(Hideaki Nakashima and Nobuo Nagai, A Study on Physical Fitness of Female Students Jap. J. Phys. Educ., Vo. 23, No. 3, Dec., pp. 229 239)

\section{I 楮 豆}

体育実技を指導する際には学生の体力の 現状を 把握し，授業の生体目担度およびその効果につい て十分に配虑することが重要であり，現在までに もこれらのことを論じた報告が数多くある。

体力に関与している因子の中には過去の運動経 験，肥瘦度等が考兄られる．運動経験と体力に関 して検討した報告では，いずれも運動経験の多い 者が少ない者より体力が優れていることを指摘し ている18,27,29,81)。 また肥満者等の体力に関しては 肥満者が劣る ${ }^{17,20)}$, 肥満者も瘦身者も劣る ${ }^{5,9)}$, 皮 下脂肪の壓さと相関がない, 6,18$)$ ，等の結果が 報告 されている.

体育実技授業時の生体負担度に関しては，心拍 数や \% $\mathrm{VO}_{2} \max$ の面から検討し，それぞれ 120 〜 140 beats $/ \mathrm{min}$ ，50\%以上であると報告されてい $3^{4,12,22,32)}$ 。 また，授業の体力に対する効果につ いては，特別なトレーニングを授業に組み入れた もの ${ }^{8,21,23)}$ ，一般的な授業のみ ${ }^{7,24,26,28,80,83)}$, およ び，その両者を検討した ${ }^{3,10)}$ ．報告があるが，い ずれす効果はあるとしている.

以上のごとく，それぞれの目的に応じた個別的 な検討はなされているが，同一被検者について多 方面から分析した報告はなく，一般的な女子学生 の体力の現状に関しては，十分な解析が加えられ ているとは言えないそこで，女子学生について 過去の中・高等学校期の運動部経験年数別, およ び，現在のローレル指数別に体力を検討すると共 に，当該学生の実技授業中の心拍数を測定し，さ らに, 古くBrouha, L. ${ }^{1}$ が報告しているよ5に体 力別に授業の効果を検討した。

\section{II 方 法}

測定項目は文部省の体力診断テスト ${ }^{16)}$ に肺活 量, 上体起しを加えた 9 項目で，測定は一般的に
実施されている方法に準拠した。なお，上体起し は 3 秒に 1 回のテンポで行い, 50 回を上限として 打切った。

対象は18，19才の新入学生 1,064 名である. 测 定は大学および短期大学入学後の第 1 回目の体育 実技授業時（4 月下旬）と 12 月中旬の 2 回実施し た. 同時に中・高校期の運動部所属年数を質問紙 法により調査し， $\mathrm{a}$;末経験と 6 カ月未満, $\mathrm{b} ; 6$ 力月以上 2 年末満, $\mathrm{c} ; 2$ 年以上 5 年末満, $\mathrm{d}$; 5 年以上，と 4 群に分けた。その分布は $\mathrm{a}$ が $49 \%$ ， bが $25 \%$ ， cが20\%，そしてdが6\%であった (図 1 ).

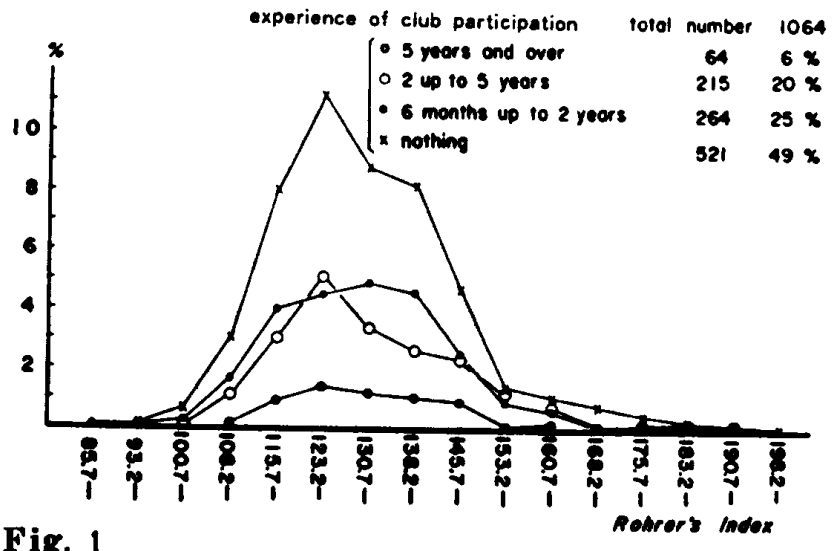

Distribution of the Rohrer's index. (Subjects were divided into four groups in terms of participation in organized club training.)

ローレル指数については，できるだけ多くのグ ループに分けるため, 今回の被検学生の平均值 $134.4 \pm 15.0$ から，単に $\frac{1}{2}$ S Dずっで区分した。 つまり図1のX軸として示してあるように，王士 $\frac{1}{4}$ S Dは130.7〜138.1 であり， $\bar{x}+\frac{1}{4}$ S D以上 $+\frac{3}{4} \mathrm{~S} D$ 末満は138.2 145.6, $\bar{x}+\frac{3}{4} \mathrm{~S} \mathrm{D}$ 以上 $\bar{x}$ $+\frac{5}{4} \mathrm{~S} \mathrm{D}$ 末満は145.7〜153.1，………゙ある.

体力区分については，集団を対象に指導する場 合，体力的に強・中・弱を前提として㬰施するの が普通であるが，ここでは，より強い・より弱い 
Table 1 Evaluation of physical fitness divided into 5 levels.

\begin{tabular}{ll|l|l|l|l} 
& \multicolumn{1}{c}{$\begin{array}{c}\text { side step } \\
\text { test } \\
\text { times }\end{array}$} & \multicolumn{1}{c|}{$\begin{array}{c}\text { vertical } \\
\text { jump }\end{array}$} & $\begin{array}{c}\text { back } \\
\text { strength } \\
\text { Kg }\end{array}$ & $\begin{array}{c}\text { grip } \\
\text { strength } \\
\text { Kg }\end{array}$ \\
\hline A & $\overline{\mathbf{x}}+\frac{3}{2}$ SD and over & $41.7-$ & $46.3-$ & $102.6-$ & $35.8-$ \\
B & $\bar{x}+\frac{1}{2}$ SD up to $\bar{x}+\frac{3}{2}$ SD & $38.2-41.6$ & $40.8-46.2$ & $86.9-102.5$ & $31.6-35.7$ \\
C & over $\bar{x}-\frac{1}{2}$ SD up to $\bar{x}+\frac{1}{2}$ SD & $34.8-38.1$ & $35.5-40.7$ & $71.2-86.8$ & $27.5-31.5$ \\
D & $\bar{x}-\frac{3}{2}$ SD through $\bar{x}-\frac{1}{2}$ SD & $31.2-34.7$ & $30.0-35.4$ & $55.5-71.1$ & $23.3-27.4$ \\
E & $\bar{x}-\frac{3}{2}$ SD and below & -31.1 & -29.9 & -55.4 & -23.2
\end{tabular}

\begin{tabular}{|c|c|c|c|c|c|}
\hline & $\begin{array}{r}\text { step test } \\
\text { scores }\end{array}$ & $\begin{array}{c}\text { trunk } \\
\text { extension } \\
\mathrm{cm}\end{array}$ & \begin{tabular}{|c|} 
standing \\
trunk fiexion \\
$\mathrm{cm}$
\end{tabular} & \begin{tabular}{|c} 
vital \\
capacity \\
mi
\end{tabular} & $\begin{array}{l}\text { sit up } \\
\text { times } \\
\end{array}$ \\
\hline $\mathbf{A}$ & $63.4-$ & $67.8-$ & $23.3-$ & $3401-$ & $39.8-$ \\
\hline B & $55.9-63.3$ & $61.0-67.7$ & $18.2-23.2$ & $2975-3400$ & $29.7-39.7$ \\
\hline C & $48.4-55.8$ & $54.3-60.9$ & $13.3-18.1$ & $2550-2974$ & $19.8-29.6$ \\
\hline D & $40.9-48.3$ & $47.5-54.2$ & $8.2-13.2$ & $2124-2549$ & $9.7-19.7$ \\
\hline $\mathbf{E}$ & -40.8 & -47.4 & -8.1 & -2123 & -9.6 \\
\hline
\end{tabular}

グループを独立させ，5段階とした（表 1 ).すな わち，4月の測定平均值と標準偏差から, $\bar{x}+\frac{3}{2}$ $\mathrm{S} D$ 以上をA群, $\bar{x}+\frac{1}{2} \mathrm{~S} \mathrm{D}$ 以上 $+\frac{3}{2} \mathrm{~S} \mathrm{D}$ 末満 をB群, $x-\frac{1}{2} \mathrm{SD} ら \bar{x}+\frac{1}{2} \mathrm{~S} \mathrm{D}$ を群, $\bar{x}$ $\frac{3}{2} \mathrm{~S} D$ Dがー- $\frac{1}{2} \mathrm{~S}$ D以下をD群, $\bar{x}-\frac{3}{2} \mathrm{~S}$ D以 下をE群とした。

体青実技授業中の運動强度を知る目的で，実技 で探用している4種目（バレーボール，軟式庭 球，卓球，バドミントン)について，被検者を無 作為に選び，無線搬送により心拍を記録した。授 業は週 1 回90分で, 内容は出欠確認等10分, ラン ニング $3 \sim 5$ 分, 準備運動として徒手体操や租体 操的補强運動等 $10 \sim 15$ 分，その後主運動に入る が，場所が狭いため，同時に50〜60名を連動させ ることは危險なので，交代で実施することが多 く，運動と休䚑の割合いは約25分ずつ，したがっ て実質総運動時間は 1 人当り，およそ 45 分であ る.この間の心拍数は，完全休憩を除いて平均す ると，バレーボール授業 $(\mathrm{n}=7) \quad 138.5 \pm 16.0$ beats $/ \mathrm{min}$, 軟式庭球授業 $(n=4) 137.7 \pm 17.9$ beats $/ \mathrm{min}$, 卓球とバドミントン授業（この授業 では 1 時限内に雨種目を実施， $\mathrm{n}=2$ ） $136.9 \pm$ 15. 3beats/min であった。

平均值の差の検定は $\mathrm{t}$ 検定で行い，分散が同質 でないもの，すなわち表 $2 \cdot 3 \cdot 4$ の括弧印，お よび表 5 は Welch の法によった.

\section{III 結 果}

\section{1. 運動部経験年数別体力}

図 2 に各項目について，運動部経験年数別，口 ーレル指数別に平均值と標準偏差をプロットし た。その結果，体力は運動部経験年数の多い順に 高い傾问が認められる.

運動経験年数の多少で分けた 4 群間の差の検定 は，ローレル指数区分のモードに相当する 123.2 〜130.6の対象について実施した（表 2 ），柔軟性 の項目である立位体前届と上体反しは，どの群間 にも有意な差が認められないが，その他の項目 は，ほとんどすべて 5 年以上の運動部経験者であ るd群が，他群より有意に高い值を示している.未 経験者の $\mathrm{a}$ 群と 2 年未満の $\mathrm{b}$ 群を比較すると，握 

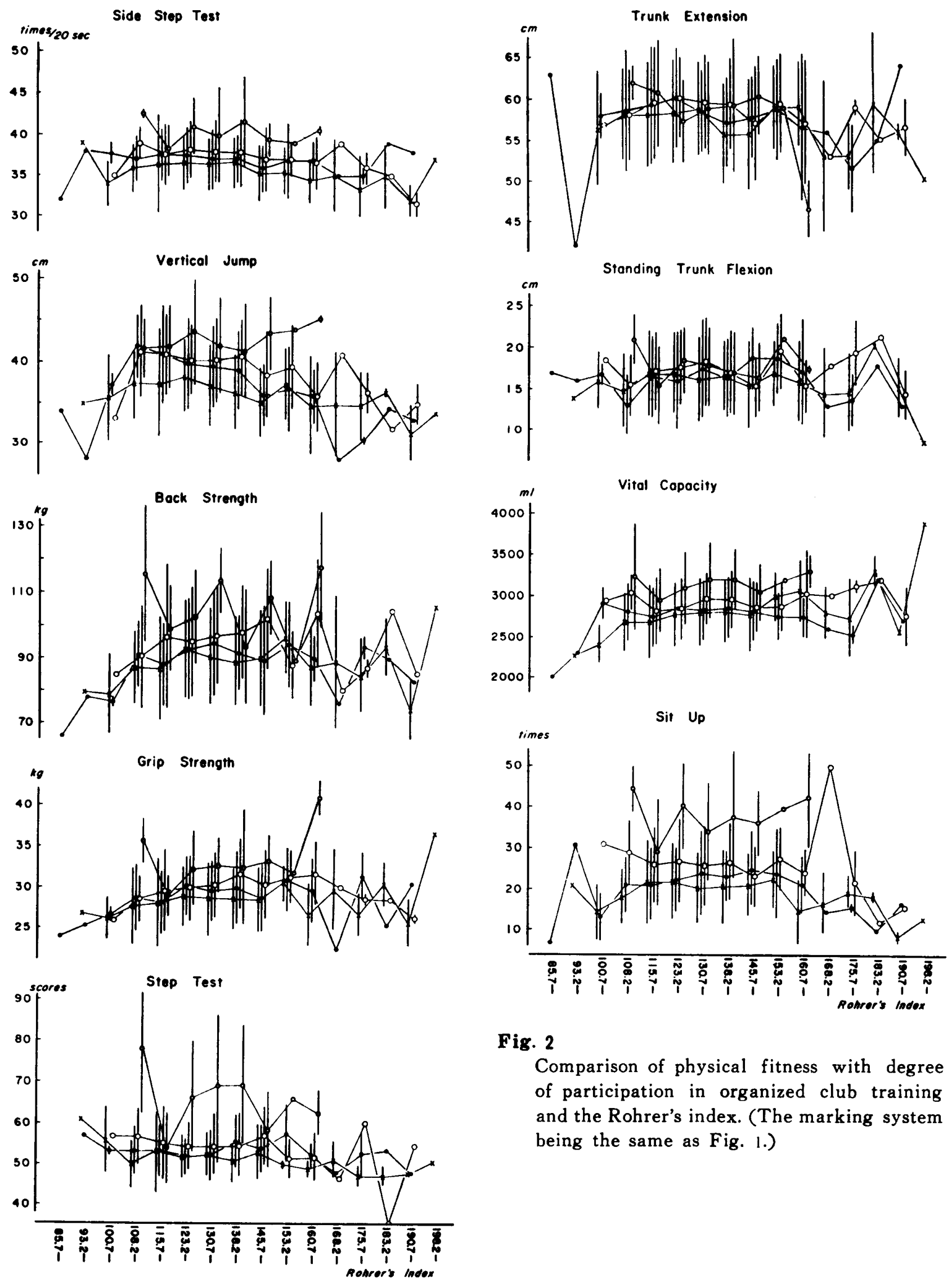

Fig. 2

Comparison of physical fitness with degree of participation in organized club training and the Rohrer's index. (The marking system being the same as Fig. 1.) 
Table 2 T-values between the groups divided in organized club training. (The Rohrer's index is $123.2-130.6$ together with $a, b, c$ and d.)

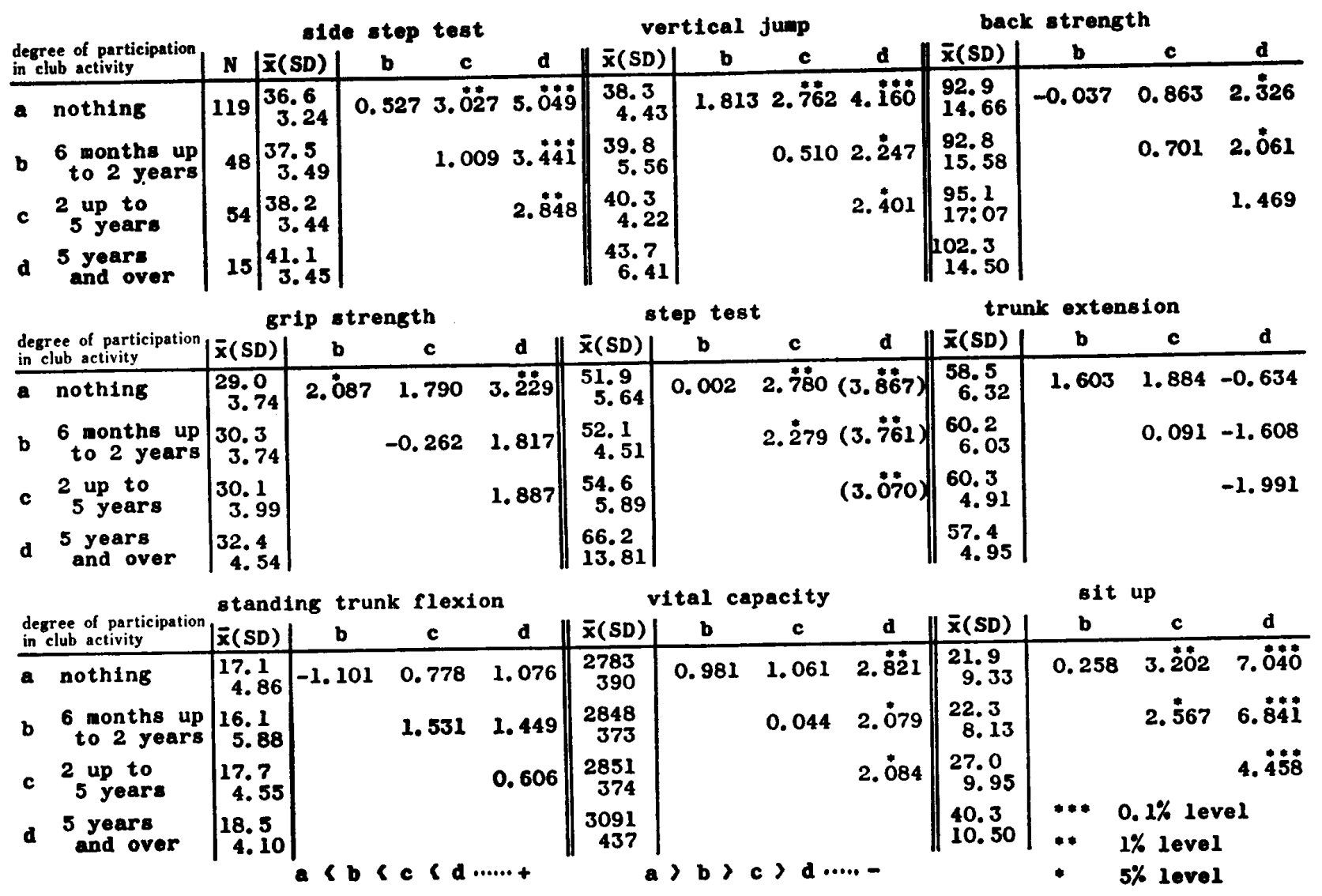

Table 3 T-values between the groups divided in the Rohrer's index.

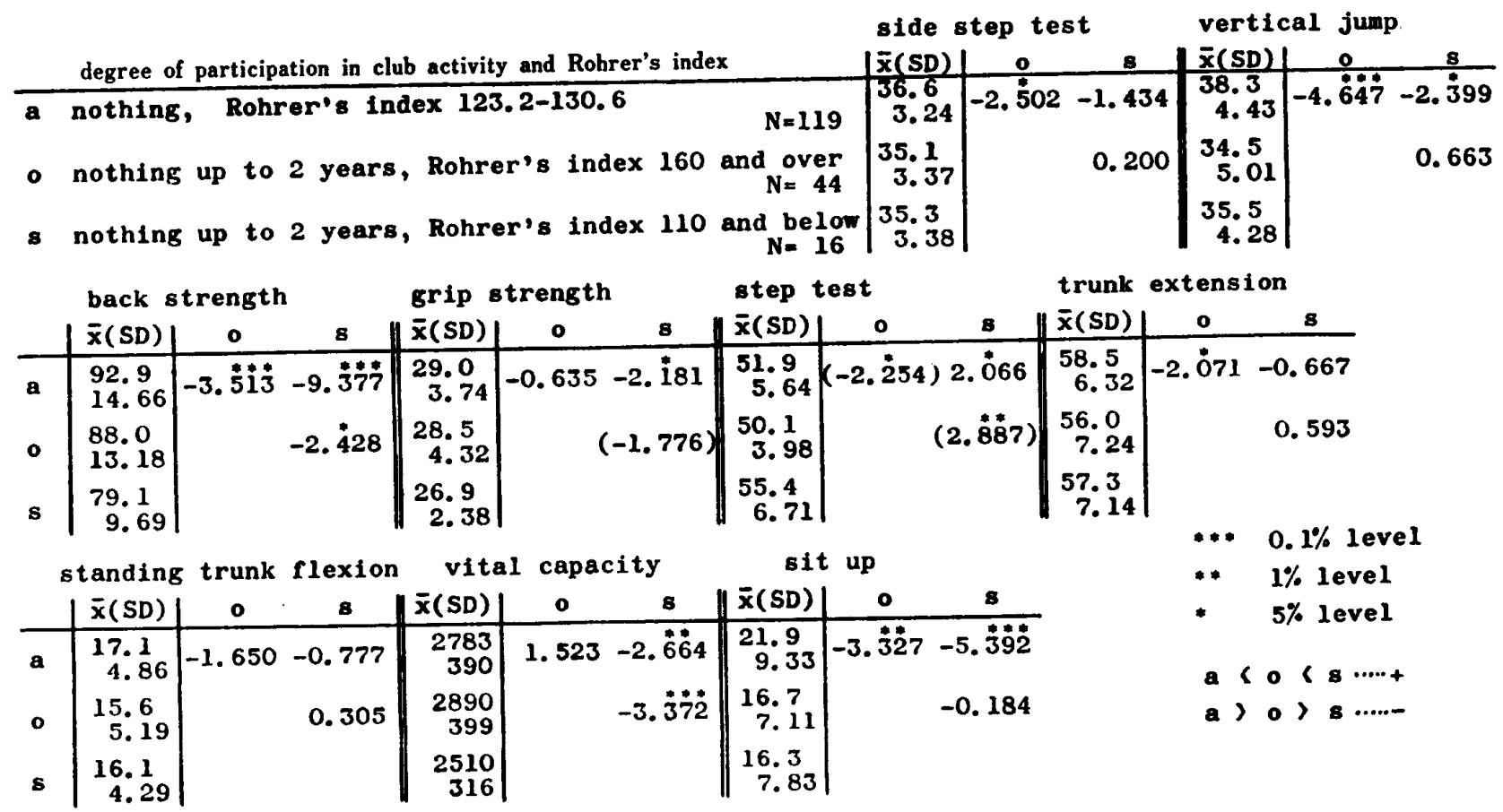


Table 4 Comparison between the group of the Rohrer's index 123.2-130.6 and the other groups.

\begin{tabular}{|c|c|c|c|c|c|c|c|c|c|c|c|c|c|}
\hline & & ature & Woight & $\begin{array}{c}\text { Rohror's } \\
\text { Index }\end{array}$ & $\begin{array}{l}\text { side } \\
\text { stop }\end{array}$ & $\begin{array}{c}\text { vortical } \\
\text { Jump }\end{array}$ & trengt! & strength & test & $\begin{array}{l}\text { runt } \\
\text { oxtensi }\end{array}$ & lexion & apadi & $t$ up \\
\hline $\begin{array}{l}\text { nothlng } \\
\text { R. I. } 123.219 \\
\end{array}$ & $\begin{array}{l}\overline{\mathbf{x}} \\
\mathbf{S D} \\
\end{array}$ & \begin{tabular}{|c}
156.8 \\
4.43 \\
\end{tabular} & $\begin{array}{r}49.2 \\
4.22 \\
\end{array}$ & $\begin{array}{r}127.2 \\
8.22 \\
\end{array}$ & $\begin{array}{r}36.6 \\
3.24 \\
\end{array}$ & $\begin{array}{c}38.3 \\
4.45 \\
\end{array}$ & $\begin{array}{l}92.9 \\
14.66 \\
\end{array}$ & $\begin{array}{r}29.0 \\
3.74\end{array}$ & $\begin{array}{r}51.9 \\
5.64 \\
\end{array}$ & $\begin{array}{r}38.8 \\
6.32 \\
\end{array}$ & $\begin{array}{r}17.1 \\
4.86 \\
\end{array}$ & $\begin{array}{r}2783 \\
390 \\
\end{array}$ & $\begin{array}{r}21.9 \\
9.33 \\
\end{array}$ \\
\hline $\begin{array}{l}2 \text { years } \\
\text { R. I. } 100,7-106.1\end{array}$ & $\begin{array}{l}\overline{\mathbf{x}} \\
\text { SD } \\
\mathbf{t} \\
\mathbf{P}<\end{array}$ & $\begin{array}{c}158.3 \\
2.88 \\
1.044 \\
-\end{array}$ & $\begin{array}{r}42.0 \\
2.68 \\
-5.241 \\
0.001\end{array}$ & $\begin{array}{r}105.8 \\
-29.97 \\
-29.295 \\
0.001\end{array}$ & $\begin{array}{l}35.1 \\
2.98 \\
-1.404 \\
-\end{array}$ & $\begin{array}{l}36.1 \\
4.58 \\
-1.403\end{array}$ & $\begin{array}{l}78.4 \\
10.52 \\
-3.038 \\
0.01\end{array}$ & $\begin{array}{l}26.4 \\
2.22 \\
-3.150 \\
0.05\end{array}$ & $\begin{array}{l}55.5 \\
6.95 \\
5.607 \\
0.001\end{array}$ & $\begin{array}{l}56.9 \\
5.99 \\
-0.766 \\
-\end{array}$ & $\begin{array}{c}16.4 \\
2.98 \\
-0.445\end{array}$ & $\begin{array}{c}2564 \\
319 \\
-1.716\end{array}$ & $\begin{array}{c}14.1 \\
6.67 \\
-2.569 \\
0.05\end{array}$ \\
\hline R. I. $108.2-115.6$ & $\begin{array}{l}\overline{\mathbf{x}} \\
\text { SD } \\
\mathbf{t} \\
\mathbf{P}< \\
\end{array}$ & $\begin{array}{c}159.3 \\
3.88 \\
3.450 \\
0.001 \\
\end{array}$ & $\begin{array}{r}45.9 \\
3.50 \\
-4.825 \\
0.001 \\
\end{array}$ & $\begin{array}{r}113.4 \\
1.97 \\
-37.891 \\
0.001\end{array}$ & $\begin{array}{c}36.3 \\
2.94 \\
-0.561 \\
-\end{array}$ & $\begin{array}{c}38.9 \\
4.68 \\
0.788 \\
- \\
\end{array}$ & $\begin{array}{l}\text { 88.? } \\
11.03 \\
-1.810 \\
-\end{array}$ & $\begin{array}{l}28.2 \\
4.52 \\
-1.184 \\
-\end{array}$ & $\begin{array}{r}51.7 \\
5.71 \\
-0.208 \\
- \\
\end{array}$ & $\begin{array}{c}58.3 \\
6.26 \\
-0.187 \\
- \\
\end{array}$ & $\begin{array}{r}14.8 \\
4.5 \\
-3 . \\
0.5\end{array}$ & $\begin{array}{l}2727 \\
355 \\
-0.875 \\
-\end{array}$ & $\begin{array}{l}19.9 \\
\text { 6.55 } \\
-1.372 \\
-\end{array}$ \\
\hline R.I. $153 . \underset{n=25}{2-160.6}$ & $\begin{array}{l}\bar{x} \\
\mathbf{s b} \\
\mathbf{t} \\
\mathbf{P r}\end{array}$ & $\begin{array}{c}154.1 \\
4.41 \\
-2.753 \\
0.01\end{array}$ & $\begin{array}{l}57.1 \\
5.02 \\
8.132 \\
0.001\end{array}$ & $\begin{array}{r}155.9 \\
2.01 \\
59.298 \\
0.001\end{array}$ & $\begin{array}{l}36.2 \\
3.66 \\
-0.544 \\
-\end{array}$ & $\begin{array}{l}36.7 \\
5.14 \\
-1.584 \\
-\end{array}$ & $\begin{array}{l}95.7 \\
12.02 \\
0.919 \\
-\end{array}$ & $\begin{array}{l}30.9 \\
2.95 \\
2.373 \\
0.05\end{array}$ & $\begin{array}{l}53.2 \\
6.27 \\
1.444 \\
-\end{array}$ & $\begin{array}{l}59.0 \\
5.30 \\
0.365 \\
-\end{array}$ & $\begin{array}{l}17.7 \\
4.59 \\
0.563 \\
-\end{array}$ & $\begin{array}{l}2900 \\
313 \\
1.400 \\
-\end{array}$ & $\begin{array}{l}23.3 \\
9.04 \\
0.681 \\
-\end{array}$ \\
\hline R. I. $160 . \underset{n=19}{7-168.1}$ & $\begin{array}{l}\bar{x} \\
\text { sD } \\
t \\
\text { Pr }\end{array}$ & $\begin{array}{c}153.1 \\
4.14 \\
-3.387 \\
0.001\end{array}$ & $\begin{array}{l}58.9 \\
3.03 \\
8.948 \\
0.001\end{array}$ & $\begin{array}{r}163.1 \\
2.72 \\
62.883 \\
0.001\end{array}$ & $\begin{array}{l}35.3 \\
2.83 \\
-1.640 \\
-\end{array}$ & $\begin{array}{l}35.2 \\
5.29 \\
-2.734 \\
0.01\end{array}$ & $\begin{array}{l}88.5 \\
10.68 \\
-1.247\end{array}$ & $\begin{array}{l}28.0 \\
4.18 \\
-1.057 \\
-\end{array}$ & $\begin{array}{l}50.4 \\
3.36 \\
-1.120 \\
-\end{array}$ & $\begin{array}{l}58.3 \\
6.95 \\
-0.125 \\
-\end{array}$ & $\begin{array}{l}16.5 \\
5.58 \\
-0.486 \\
-\end{array}$ & $\begin{array}{l}2947 \\
366 \\
1.710\end{array}$ & $\begin{array}{l}17.3 \\
8.37 \\
-2.009 \\
0.05\end{array}$ \\
\hline R. I. $168 . \underset{n=9}{2-175,6}$ & $\begin{array}{l}\bar{x} \\
\text { SD } \\
t \\
\text { P< }\end{array}$ & $\begin{array}{c}154.8 \\
5.76 \\
-1.265 \\
-\end{array}$ & $\begin{array}{l}63.6 \\
7.24 \\
(5.562) \\
0.001\end{array}$ & $\begin{array}{r}171.0 \\
17.98 \\
57.046 \\
0.001\end{array}$ & $\begin{array}{l}35.1 \\
4.25 \\
-1.296\end{array}$ & $\begin{array}{l}34.1 \\
6.37 \\
-2.623 \\
0.01\end{array}$ & $\begin{array}{l}87.4 \\
19.57 \\
-0.667 \\
-\end{array}$ & $\begin{array}{c}29.1 \\
5.24 \\
0.074\end{array}$ & $\begin{array}{l}50.8 \\
4.72 \\
-0.566\end{array}$ & $\begin{array}{l}53.3 \\
8.79 \\
-2.288 \\
0.05\end{array}$ & $\begin{array}{l}14.4 \\
5.28 \\
-1.585 \\
-\end{array}$ & $\begin{array}{c}2782 \\
302 \\
-0.007\end{array}$ & $\begin{array}{r}16.9 \\
7.22 \\
-1.560\end{array}$ \\
\hline R. I. $175 . \underset{n=B_{8}}{7-183}$ & $\begin{array}{l}\bar{x} \\
\text { SD } \\
t \\
\text { PC }\end{array}$ & $\begin{array}{c}151.2 \\
6.23 \\
-3.333 \\
0.01\end{array}$ & $\begin{array}{c}60.6 \\
4.87 \\
7.231 \\
0.001\end{array}$ & $\begin{array}{c}179.1 \\
1.57 \\
64.528 \\
0.001\end{array}$ & $\begin{array}{c}34.1 \\
3.33 \\
-2.092 \\
0.05\end{array}$ & $\begin{array}{l}33.7 \\
4.17 \\
-2.831 \\
0.01\end{array}$ & $\begin{array}{l}86.9 \\
10.46 \\
-1.129 \\
-\end{array}$ & $\begin{array}{c}28.2 \\
3.39 \\
-0.584 \\
-\end{array}$ & $\begin{array}{l}48.8 \\
4.79 \\
-1.506 \\
-\end{array}$ & $\begin{array}{l}32.6 \\
4.55 \\
-2.575 \\
0.05\end{array}$ & $\begin{array}{l}14.5 \\
4.50 \\
-1.460 \\
-\end{array}$ & $\begin{array}{l}2680 \\
117 \\
-0.716 \\
-\end{array}$ & $\begin{array}{c}18.9 \\
3.98 \\
-0.879 \\
-\end{array}$ \\
\hline 1. $183.2-$ & $\begin{array}{l}\bar{x} \\
\mathbf{g D} \\
t \\
p<\end{array}$ & $\begin{array}{c}152.7 \\
5.58 \\
-2.324\end{array}$ & $\begin{array}{l}68.3 \\
7.34 \\
(6.322) \\
0.001\end{array}$ & $\begin{array}{c}191.1 \\
5.71 \\
(11.670) \\
0.001\end{array}$ & $\begin{array}{r}35.4 \\
3.50 \\
-0.941\end{array}$ & $\begin{array}{r}33.9 \\
2.71 \\
-2.579 \\
0.05\end{array}$ & $\begin{array}{l}88.0 \\
12.72 \\
-0.859\end{array}$ & $\begin{array}{l}29.5 \\
4.36 \\
0.338\end{array}$ & $\begin{array}{l}49.4 \\
3.26 \\
-1.152\end{array}$ & $\begin{array}{l}57.2 \\
6.08 \\
-0.526 \\
-\end{array}$ & $\begin{array}{l}15.9 \\
4.46 \\
-0.633\end{array}$ & $\begin{array}{l}3081 \\
466 \\
1.929 \\
-\end{array}$ & $\begin{array}{l}13.4 \\
4.37 \\
-2.376 \\
0.05\end{array}$ \\
\hline
\end{tabular}

Table 5 Effect of physical education on the physical fitness of 5 levels.

\begin{tabular}{|c|c|c|c|c|c|c|c|c|c|}
\hline & $\begin{array}{l}\text { Side stop toet } \\
\text { times }\end{array}$ & $\begin{array}{c}\text { vertical jump } \\
\text { cal }\end{array}$ & $\begin{array}{l}\text { beck at rongth } \\
\text { kg }\end{array}$ & srip strength & $\begin{array}{c}\text { etop test } \\
\text { ecores }\end{array}$ & $\begin{array}{l}\text { trunk extension } \\
\text { cm }\end{array}$ & $\begin{array}{l}\text { thending } \\
\text { truak flexion } \\
\text { cal }\end{array}$ & $\begin{array}{c}\text { vitel capacity } \\
\text { el }\end{array}$ & $\begin{array}{l}\text { sit up } \\
\text { timos }\end{array}$ \\
\hline & Apr. Dec. & Apr. Dec. & Apr. Dec. & Apr. Doc. & Apr. Dec. & Apr. Dec. & Apr. Dec. & Apr. Doc. & Apr. Dec. \\
\hline $\begin{array}{l}\bar{x} \\
\mathbf{S D} \\
n \\
n \\
i \\
p<\end{array}$ & 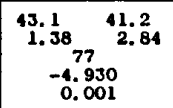 & 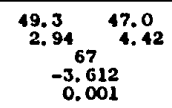 & $\begin{array}{c}114.1 \\
10,95 \\
87.35 \\
-47.781 \\
-4.781 \\
0.001\end{array}$ & $\begin{array}{c}37.9 \\
1.77{ }^{35.8} \\
3.00 \\
-5.117 \\
0.001\end{array}$ & $\begin{array}{cc}69.8 & 66.7 \\
7.03 & 90.24 \\
-3.571 \\
-3.501\end{array}$ & $\begin{array}{cc}69.5 & 67.8 \\
1.86 & 3.26 \\
34.26 \\
-2.919 \\
0.01\end{array}$ & $\begin{array}{cc}25.5 & 24.4 \\
2.10 & 3.09 \\
644.44 \\
-2.444 \\
0.02\end{array}$ & $\begin{array}{c}36566 \\
197 \\
153 \\
-3592 \\
-3.108 \\
0.01\end{array}$ & $\begin{array}{cc}44.4 & 58.7 \\
4.25 & 6.92 \\
666 & =98 \\
-5.580 \\
0.001\end{array}$ \\
\hline 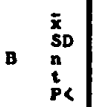 & $\begin{array}{cc}39.7 & 38.8 \\
0.79 & 2.40 \\
-255 & 2.460 \\
0.001 & \\
0.401\end{array}$ & $\begin{array}{cc}43.0 & 41.9 \\
1.60 & 3.92 \\
240 & 3.12 \\
-1.632 \\
0.001\end{array}$ & $\begin{array}{cc}93.9 & 92.0 \\
4.99 & 10.94 \\
198 & 1.596 \\
-1.5\end{array}$ & 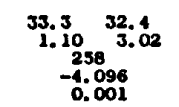 & $\begin{array}{cc}58.9 & 58.5 \\
2.45 & \begin{array}{c}58.49 \\
143 \\
-0.892\end{array} \\
-\end{array}$ & $\begin{array}{cc}63.6 & 62.9 \\
1.84 & 3.64 \\
311 & 3.64 \\
-3.240 & 0.01\end{array}$ & $\begin{array}{c}20.4 \quad 20.0 \\
1.43 \quad 282.59 \\
-282 \\
-2.537 \\
0.02\end{array}$ & $\begin{array}{cc}3152 & 3132 \\
1222 & 273 \\
240 & 273 \\
-1.034 & -\end{array}$ & $\begin{array}{c}32.2 \\
2.29 \\
207.4 \\
-1.835 \\
-1.87\end{array}$ \\
\hline 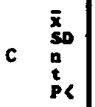 & 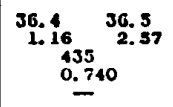 & $\begin{array}{c}38.2 \\
1.388 \\
1.618 \\
1.68\end{array}$ & $\begin{array}{c}78.3 \quad 83.1 \\
4.14 \\
372 \\
37.76 \\
8.742 \\
0.001\end{array}$ & $\begin{array}{c}29.7 \\
1.28 \\
{ }_{386}^{29.7} \\
0 \\
-\end{array}$ & $\begin{array}{c}51.8 \\
2.14 \\
333.6 \\
7.04 \\
7.984 \\
0.001\end{array}$ & $\begin{array}{cc}57.8 & 50.1 \\
1.78 & 389 \\
389 & 3.70 \\
2.046 \\
0.05\end{array}$ & $\begin{array}{cc}16.0 & 16.2 \\
1.48 & 2.20 \\
372 & 2.040 \\
1.040 & \end{array}$ & $\begin{array}{cc}2731 & 2807 \\
115 & 279 \\
451 & 279 \\
3.937 \\
0.001\end{array}$ & 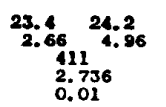 \\
\hline 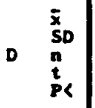 & $\begin{array}{c}33.1 \\
0.79 \\
178.3 \\
6.27 \\
6.482 \\
0.001\end{array}$ & $\begin{array}{c}33.4 .45 \\
2.65 \\
25.11 \\
240 \\
7.676 \\
0.001 \\
0.001\end{array}$ & $\begin{array}{c}65.2 \\
4.48 \\
4.4 .0 \\
243 \\
13.157 \\
0.001\end{array}$ & 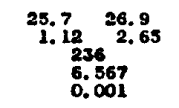 & $\begin{array}{c}45.7 \\
1.86 \\
211 \\
12.53 \\
12.977 \\
0.001\end{array}$ & $\begin{array}{cc}51.5 & 53.4 \\
1.98 & { }^{4.27} \\
177 & 531 \\
0.001\end{array}$ & $\begin{array}{cc}11.2 & 12.2 \\
1.43 & 2.72 \\
206 & 2.72 \\
1.388 \\
0.001\end{array}$ & $\begin{array}{cc}2396 & 2326 \\
120 & 2273 \\
217 & 270 \\
6.407 \\
0.001\end{array}$ & $\begin{array}{cc}14.8 & 17.6 \\
2.66 & 3.53 \\
258 & 3.58 \\
7.2238 \\
0.001\end{array}$ \\
\hline $\begin{array}{ll} & \overline{\mathbf{x}} \\
\mathbf{3 0} & \mathbf{n} \\
\mathbf{t} & \mathbf{p l}\end{array}$ & 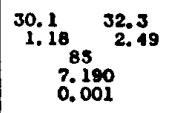 & $\begin{array}{cc}26.9 & 30.8 \\
2.52 & 3.84 \\
5.52 & 6.518 \\
0.001 & \\
0.001\end{array}$ & $\begin{array}{cc}50.5 & 62.9 \\
4.18 & 7.12 \\
40 & 70 \\
9.319 \\
0.001\end{array}$ & $\begin{array}{c}21.7 .7{ }^{24.1} \\
2.47 \\
66.604 \\
0.001\end{array}$ & $\begin{array}{cc}39.2 & 43.5 \\
1.34 & 2.74 \\
20.088 \\
0.001\end{array}$ & $\begin{array}{c}44.0 \\
3.3535 .9 \\
42.79 \\
2.042 \\
0.05\end{array}$ & $\begin{array}{c}5.9 \\
1.85 \\
71.81 \\
4.821 \\
0.001\end{array}$ & 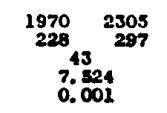 & 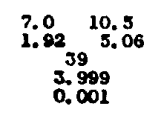 \\
\hline & roup $n=16$ & & & & & & & & \\
\hline $\begin{array}{l}\overline{\mathbf{x}} \\
\mathbf{S p D} \\
\mathbf{t} \\
\mathbf{P}<\end{array}$ & $42.7 \quad 43.0$ & & $\begin{array}{c}1.6 \\
2.07 \\
2.08 .9 \\
2.08 \\
0.05\end{array}$ & $\begin{array}{l}35.2 \\
4.95 \\
-1.008\end{array}$ & $\begin{array}{ll}76.6 & 79.8 \\
17.36 & 14 . \\
1.562 & \end{array}$ & $\begin{array}{c}39.4 \\
0.58 \\
-0.601 \\
7.07\end{array}$ & 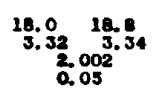 & $\begin{array}{c}3165 \\
392 \\
0.764 \\
0.05\end{array}$ & $\begin{array}{l}45.2 \\
48.2 \\
3.15\end{array}$ \\
\hline
\end{tabular}

力はb群が $5 \%$ 水準で有意に高い值を示している が，他はすべて有意な差を示さなかった、a群と 2 年以上 5 年末満のc 群を比較すると，c 群が反 復横とび，垂直とび，踏台昇降，上体起しに，有 意に高い值を示した。 b 群とc 群を比較すると, c 群は踏台昇降と上体起しが有意に高い值を示し
た。

2. 肥満者・瘦身者の体力

ローレル指数と体力の関係をみると, 叉2に示 したように，両端下がりの傾向が同える項目もあ る.そこで表 3 に示すよ5に，今回のローレル指 数区分に従って, 普通体格者と差の検定を行っ 
た.ローレル指数160.7〜168.1のグループが有意 に低いのは垂直とびと上体起し，168.2１75.6の グループは垂直とびと上体反し，175.7～183.1の グループは反復横とび，垂直とび，上体反し， 183.2 以上のグループ では垂直とびと上体起し， である. 反対に瘦身型のローレル指数 108.2〜 115.6のグループが有意に低いのは立位体前届, 100.7 108.1のグループは背筋力, 握力, 上体起 し,である.

しかしながら，一般的にはローレル指数 160 以 上をふとりすき，110以下をやせすぎと言ってい るので，160以上全員を肥満群，110以下全員を瘦 身群として平均し，普通体格者（ローレル指数 123.2～130.6）と比較した（表 4). その結果，肥 満群が普通体格者より有意に低いのは 5 項目（反 復横とび，垂直とび, 背筋力, 上体反し, 上体起 し）で，その逆は 1 項目むない。他方，瘦身者が 普通体格者より有意に低いのも5 項目（垂直と び, 背笳力, 握力, 肺活量, 上体起し) で, その 逆は踏台昇降 1 項目である. 肥満群と瘦身群を比 較すると，肥満群が有意に高いのは背筋力と肺活 量, その逆は踏台昇降である.

3. 体力区分別授業効果

表 5 は体力区分別の 4 月と 12 月の測定值，およ び，その差 $(\mathrm{t})$ を示したものである. 最も体力 の優れていたA群はすべて有意に低下，逆に劣っ ていた D・E群はすべて有意に上昇している．ま た， B・C群は有意な項目とそ5でない項目があ ろが，B群はすへて下降，C群はすべて上昇傾向 を示した。なお，被検学生の中で，授業以外に定 期的なトレーニングを実施している 者は表 5 の下 段に示した卓球部・軟式庭球部の16名のみであ る.

\section{IV 考宗}

\section{1. 運動経験について}

運動経験の調査では学校差・種目差・個人の参 加態度等を考虑しなければ実質的運動量の多少を 論ずることはできない。しかし今回の研究は, 詳 細なトレーニング効果の論議ではないので，単 に, 種目や正・補欠選手にかかわらず, 何年間運 動部に所属していたか，について集計した。その
結果，ほとんど部活動に参加したことのない者が 䄪半数， 2 年末満を加光ると $74 \%$ に達してお り, 都会地の女子中・高校生の運動部への参加の 少なさを浮き彫りにするすのである.

運動部経験の多少による体力差について，八 木 ${ }^{311}$ は「運動量の大小によって形態の差異はない が身体充実度において長期間部活動を行った者が 優れ, 機能・運動能力の項目にも差異があり, 又 運動の種類によっても差異があった」と報告して いる. 松元と沢田 ${ }^{133}$ は「中学・高校を通じて運動 部に所属していた者の体力が 1 番優れており，中 学のみで所属していた者は筋支配能力面, 高校の みで所属していた者は筋力的面が上回る傾向がみ られた」と報告している. 德永と橋本 ${ }^{29)}$ は「運動 経験と顕著な関係が認められるのは量育, 周育, 幅育, 筋力, 敏捷性, 走力, 跳力である」と, ま

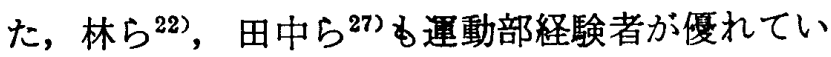
るとの報告をしている.

今回の結果も図 2 , 表 2 に示したごとく，全体 的に運動経験の多い群が高く，末経験者が低い， 経験順となっており，差の検定からも，柔軟性の 項目以外すべて 5 年以上の経験者群が有意に他群 より優れていた。適者生存の原理で，体力の高い 者が長期間部活動を珫けた，と言5ことも考えら れるので，断定はできないが，女子学生の体力は 過去の運動経験の多少に大きく左右されているも のと思われる.しかし， 2 年末満の群と末経験者 の群では握力以外すべて有意差がなく，過去は解 からないが現在では，ほとんど同一体カレベルで あると言える。

\section{2. 肥満・瘦身者について}

ローレル指数によって分けたグループ間の体力 を概観すると，多少両端下がりの傾向の認められ る項目があるので，その低下の有意性を検討した (表 3). その結果, 垂直とびに関しては確かに口 ーレル指数 160.7 168.1のグルーブからそれ以上 のグループ，いずれも有意に低い值を示してい る.しかし，他の項目では，肥満も瘦身も平均值 としては低いが，どのグループもすべて有意差が あるわけではない。同様に，著者ら ${ }^{18)}$ の自転車 エルゴメーターでの同一負荷中の心拍数，酸素搨 取量は皮下脂肪の厚さに関係がない」，生山と勝 

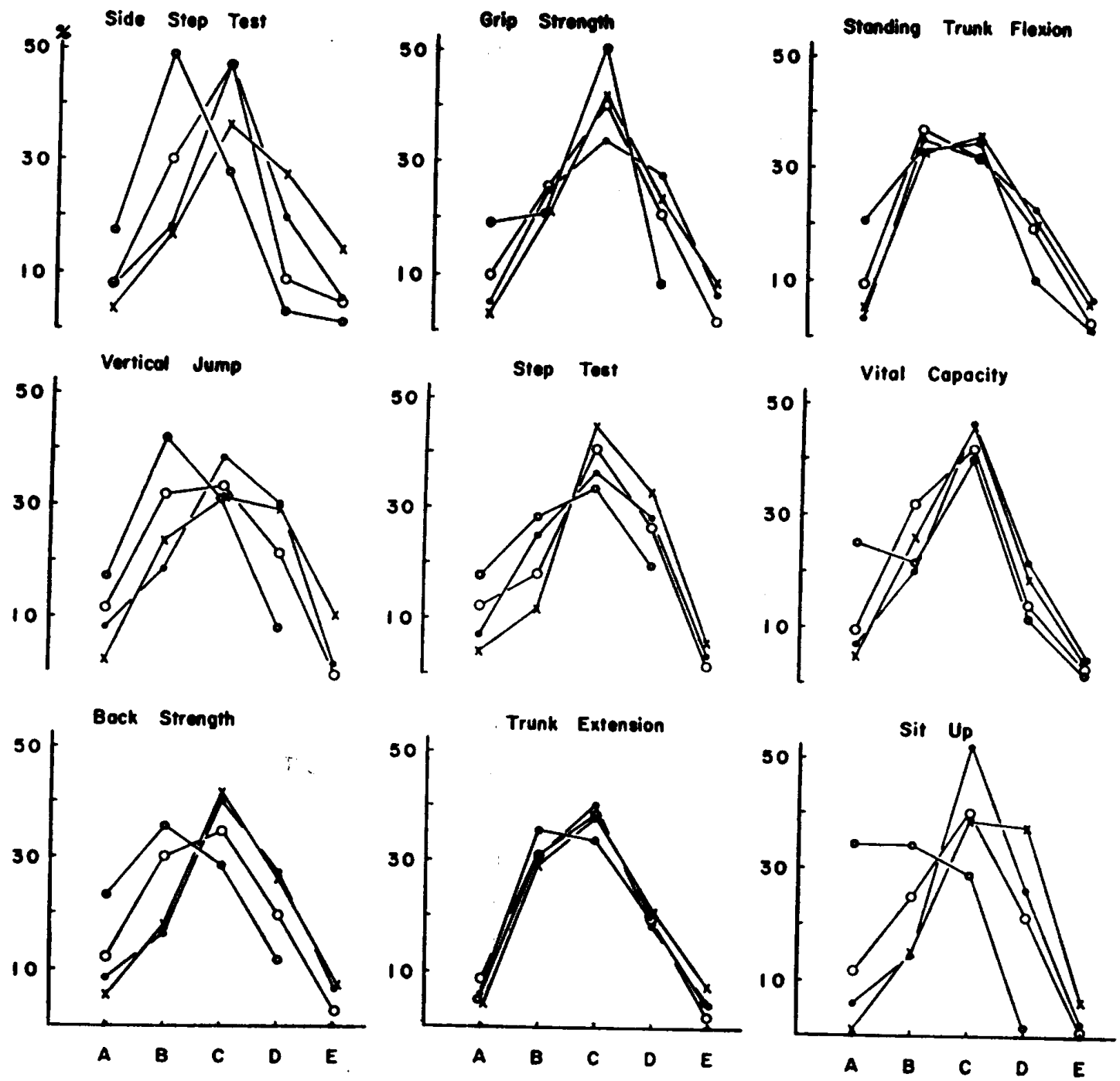

Fig. 3 Distribution of physical fitness divided into 5 levels in organized club training. (The marking systembeing the same as Fig. 1.).

$木^{6)}$ の「中高年の家庭㛎人では機能と皮下脂肪の 間に何等一定の明膫な関係を見い出し 得なかっ た」等の報告もあり，一般的な生活をしている肥 満者を一括して体力が低いとは断言できないだろ 5 .

しかしながら，表4で述べたよ5に，ローレル 指数 160 以上全員を平均し, 普通体格者と差を検 定すると，森脇ら ${ }^{17}$ 永井ら ${ }^{20}$ の報告，また， McGuinness, W.B. and A.W. Sloan ${ }^{14} の \Gamma$ fitness index と\% body weight が負の相関が高い」と の報告, 等と同様に, 肥满者が体重移動を伴 5 項 目等 5 項目が有意に低い值を示した。 反対にロー レル指数 110 以下の瘦身者群についても筋力湘定 等 5 項目，有意に低い值を示した。これは，生山

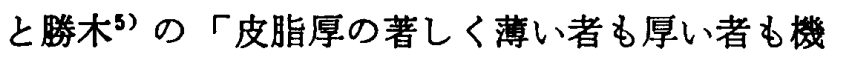

能的に劣る」，小島 ${ }^{11)}$ の文部省体力䛦断 テストの 結果「総合判定については，やせている者は太っ ている者及び平均值と比較して低い值を示してい る」，砂本 ${ }^{25)} の 「$ 細長型は肥満型より能力が低位 である」等の報告と同様，瘦身者の体力む低位に あると言える。

以上のよ5に，ローレル指数を細分して検討し た場合とローレル指数 160 以上を一括して平均し た場合とでは相反するような結果となる。この理 由については統計処理上の対象人数の問題もあろ 5が，意味するところは，肥満者は全体的に体力 が低レベルにあるが，その低さはローレル指数と は必ずしも反比例したものではなく，ローレル指 数によって体力低位肥満者を類別することには危 険がある，と言うことを示すすのだろ5。 


\section{3. 体力区分について}

4 月の湘定值によって区分した $\mathrm{A}$ ～E段階につ いて運動経験年数別に内訳をみると図 3 になる。 多年運動部経験者は当然のことながら B・C段階 が多く，未経験者はC・D段階が多い。しかし， A・B段階にランクされるのは多年運動部経験者 のみではなく,未経験者も多少おり，逆に $\mathrm{E}$ 段階は ほとんどいないが，D段階には多年運動部経験者 も若干含まれている。このことは，運動部所属年 数が長くとす種目・練習内容によっては何等, 体 力の向上に関与しない場合る考えられるので領け るが，未経験者でA段階にランクされる者につい ては遗伝的な性格・素質により，あるいは環境に よって，運動部に所属していなくとも通常の生活 の中に活動的な要素を含んでいたことになり，こ の点の解明あ興味あるところである. しかし，そ れらはごく少数例であり，総体的には過去の運動 経験の多い者が体力高レベルであり，少ない者が 低レペルにあることは間違いのない事実である。

\section{4. 授業の効果について}

体育実技授業の生体負担に関して，前田ら ${ }^{12)}$ は 「ソフトボール，バレーボールバドミントンの平 均心拍数が 145 beats $/ \mathrm{min}$, 卓球が 125 beats $/ \mathrm{min}$, 経験者ではそれぞれ20beats/min 位高い」と，横 澤ら 少ない運動を除くと $\mathrm{V}_{2} \max$ の $50 \%$ 以上の強度 で，動きの大きいグランドストロークによるラリ 一では常に70\%以上の強度にあがり，約15分間続 き90\%以上の強度にまで達する」とそれそれ報告 している。男性の被検者では広田ら"が「ハンド ボール,サッカー, ハスケットボールのゲーム中平 均170 175 beats/min, テニス, バレーボール, 卓球, 野球の守備中 120 140beats/min である」 と, 大鋸ら ${ }^{22}$ は「バスケットボール，バレーボー ル授業で120〜140beats/min，\% \% 以上であった」とそれぞれ報告している．今回の 授業中の心拍を無線搬送した結果でも，平均 138 土15beats/min であり, 生体負担としては強い運 動とは言えないだろう。

この程度の強度での体有実技を週 1 回 90 分行っ て，体力に対して影響があるかについて，体力別 に検討したが， A・B群はすべての項目が低下し
ており，高い体力群では体育授業が体力の維持や 増強に役立っていないと言える.しかし, 表 5 の 下段に training group として示したよ5に，現 在むなお卓球部・軟式庭球部でトレーニングを実 施している者達は，2 項目の低下（有意差なし） が認められるのみで，他はすべて向上（有意なる の 2 項目) しており，適切な指導があれば， $\mathbf{A} ・$ B群といえども，さらに体力の向上を望めるだろ 5 .

他方， C・D・E群のような，平均的あるいは それ以下の体力レベル者では表 5 にみられるよ5 に，現在の体育授業の生体負担強度です，有効な トレーニング刺澈となっているるのと思われる。 同様な体育実技授業の効果についての 報告では, 広田ら ${ }^{3)}$ が呼吸循環機能の向上を, 菊地ら ${ }^{10)}$ は能 力の低い者には有効，小倉ら ${ }^{24}$ は有意な項目とそ 5でない項目があるが全体的に向上，徳永と荒 井 ${ }^{28}$ は男子は上昇が顕著だが女子は影著でなく， また体力低位者が最も顕著に上昇，次いで中位 者, 体力高位者は上㫒が顕著でない, 等々 $7,26,30$, 38)，いずれも効果を認めている。ささらに授業内に トレーニングを組み入れて効果を認めた報告す多 $\left({ }^{8,10,21,28)}\right.$.

女子学生に対するトレーニングの研究で，著者 $ら^{19)}$ は「5 分間の階段昇降トレーニングの場合, $\dot{\mathrm{VO}_{2}} \mathrm{max}$ が $28 \mathrm{ml} / \mathrm{kg} \cdot \min$ 位の者では週 3 日, 31 $\mathrm{ml} / \mathrm{kg} \cdot \mathrm{min}$ 位の者は週 4 日のトレーニングが必 要である」と，石河ら ${ }^{8)}$ は種々の負荷でトレーニ ングを行い $\mathrm{r} \mathrm{VO}_{2} \max$ の $65 \%$ 位の負荷が必要であ る」と報告している。また，一卵性双生児の研究 で Mellerowicz, H. ${ }^{15)}$ は $\max$ の80\%負荷で,一 方には 6 分の運動を 6 回/週，他方には 1 日で 1 週間分 (6 分 $\times 6$ 回) を実施させ， 3 週後と 6 週 後の変化を観察し，どちらも効果があるが，分け た方がより効果が大であることを報告している.

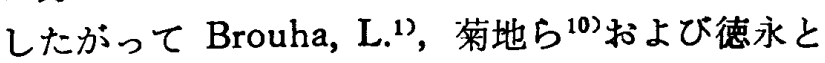
荒井 ${ }^{28)}$ 等が指摘したと同样，女子学生の場合に す，平均以下の体力レベル者には現在の週 1 回の 体育実技授業でも，体力の向上を期待でさるが， 体力高位者には強度のみならず，頻度をる増加し なければ向上は望めない。

以上の結果から, 現在の女子学生の体力水䇢 
は，過去の運動部経験年数とある程度比例してい

る. また，全体的に対象の体力水算が低いために 1 週 1 回90分間の授業でも，運動が効果的な刺激 となり，4月の測定值に比較して12月の湘定值の 向上が認められているのである。しかし，体力の 高い集団では，12月の测定時には全体的に平均值 の低減傾向が認められることから，同じ90分の授 業でも，この集団に対しては運動負荷強度が弱い ことになる。このことから，授業実施時には体力 別に負荷強度を効果的に変える 必要が生じてく る.そのため，体育実技を体力向上の観点からみ るとき，体力の能力別編成が望ましいといえよ 5 .

\section{$\mathrm{V}$ 要 的}

1. 女子学生の体力の現状を分析すると共に，体 育実技授業の影響について検討した。

2. 被検者は $18 \cdot 19$ 才の女子学生 1,064 名であ る.

3、運動経験の調查から，運動部未経験 者が 49 $\% ， 2$ 年末満が $25 \%$ ，そして 5 年以上は僅か 6 \%であった。

4. 運動経験の多少による体力差は，ほぼ経験順 であるが， 2 年末満の群は未経験者とほとんど 同一体力となっている. 他方，5 年以上の群は 他群より，ほとんどすべての項目で有意に高い 值を示した。

5. ローレル指数 160 以上, 110 以下の群を普通体 格者と比較すると，両群共に体力低位者であ る.しかし，ローレル指数を細分して比較する と，垂直とび以外は一定の低減傾向を示さない ので，ローレル指数から体力低位肥満者を類別 することには危険がある。

6. 体育実技授業は週 1 回90分で，平均心拍数は 138土15beats $/ \mathrm{min}$ となっており，運動負荷上 しては比較的軽いと言える.

7. 4 月と 12 月の体力変化を体力区分に従って 検 討すると，体力高位者はすべて下降を示し，授 業は体力の維持・増進に衝きかけていない。

しかし，平均以下の群はすべて上昇しており， 平均的な女子学生は運動, 即, 体力向上に結びつ くものと思われる，したがって，体力に応じた運
動負荷を与えるように十分配虑する必要がある。

\section{References}

1) Brouha, L., "The Step Test; A Simple Method of Measuring Physical Fitness for Muscular Work in Young Men," Res. Quart., $14: 31-36$, 1943.

2) 林千代子, 中神勝, 山中市衛, 西田弘之「大学入学 時における体格・体力の実热一某女子大学学生につい て一」日本体育学会第27回大会号：171，1976.

3）広田公一, 黒田善雄, 浅見俊雄, 小山秀哉, 水野忠 和, 片岡幸雄, 島律大宣「大学正課体青実技の教育効 果飞関する研究(1)大学新入学生の呼吸循環機能，およ び体育実技の呼吸循罢機能の向上飞およほす初果につ いて」体育学䄫要（東京大学教善学部） $6: 1-5$, 1972.

4) 広田公一, 豊田 博, 青山昌二, 遠藤郁夫, 野崎康 明, 山本恵三, 北川櫓, 古沢久夫, 中塘二三夫, 兒津 大宣, 竹内正雄, 清水教永「大学正課体育実技の教育 効果に関する研究(6)正課体育実技に的ける各種スポー ツゲーム実施中の心拍变動について」体育学䄫要（東 京大学教美学部) $7: 1-6,1973$.

5 ）生山匡，勝木新次「皮脂厚と身体機能」体力研究， $13: 36-43,1967$.

6）生山匡，勝木新次「皮脂厚と身体機能(第 2 報)」体 力研究, $14: 32-42,1968$.

7 ）石井哲子，堀切叙子「女子大学生の体力関する一 考察」日本体青学会第22回大会号：365，1971.

8 ）石河利寬, 清水䢖雄, 永井信雄, 佐藤佑「女子学生 に抢ける最大酸秦摄取量の $35 \cdot 50 \cdot 65$ 括よび $80 \%$ 強度 でのトレーニング奻果について」体育科学, 2:207一 17, 1974.

9）蒲山弥太郎, 丸山嘉久, 鳥丸卓三, 野元五造, 奥保 宏, 庵跡征洋「鹿児島大学学生の体力および運動能力 とついて，第 4 報」鹿児島大学体育科報告, $4: 25$ 33, 1968.

10）菊地武道, 広田公一, 浅見俊雄, 豊田博, 遠藤郁 夫, 戸夰晴彦, 野崎康明, ，古谷嘉邦「大学正課体青

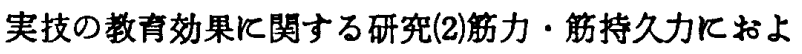
ほす奻果について」体育学紀要（東京大学教银学部） $6: 7-16,1972$.

11）小島康明「女子学生の体格と体力についての検討」 日本体育学会第22回大会号，368，1971.

12）前田喜代子, 伊藤稔, 伊藤一生, 北村栄美子「女子 学生の正課体育時に㧍ける心拍数の变動について」日 
本体青学会第27回大会号, 183，1976.

13）松元尚大, 沢田芳男「運動部所属経験の有無による 体力の比較研究」体質医学研究所報告, $25: 26-42$, 1975.

14) McGuinness, W.B. and A.W. SLOAN, "Dynamic Fitness of young adults and its relation to physical training and body fat," J. Sports Med., $11: 179-84,1971$.

15) Mellerowicz, H., "Grundlagen von Training und Leistungssteigerung." Sportarzt und Sportmedizin, 6:124-29, 1972.

16）文部省体育局「昭和 47 年度体力 - 運動能力調查報告 書」35-53， 1973.

17）森脇勤, 武田慎三, 㚼晃彰, 过幸治「肥满傾向学生 の体力 (第 4 報) 一持久性を中心として」日本体育学 会第23回大会号, 300, 1972.

18）中嶋英昭, 永井信雄, 飯島ななよ，小川新吉「女子 学生の皮下脂肪厚と体力の関係」体育学研究, 15-5 : 98, 1971 .

19）中䳋英昭, 永井信雄, 小川新吉「女子学生の持久性 トレーニング」体育学研究, 19-2：107-15, 1974.

20）永井信雄, 鈴木慎次郎, 小川新吉「肥霂女子学生の 呼吸循環機能闺関する考察」体育学研究, 14-5： 176, 1970.

21）西川渵里子,川戸安美, 三浦惠子「女子学生のサー キットトレーニング奻果に関する研究」日本体育学会 第26回大会号 : 464, 1975.

22）大鋸順，春山国広，老松信一，金子英一，小幡勝己 「体育学習における心拍数変動について」電気通信大 学学報, $26: 285-91,1976$.

23）大山䇤，天野三郎，辻浅夫，黒崎敏彦「大学の正課 体育の指望江関する一考察，一京都外大における体力 桊成講座について一」日本体育学会第23回大会号 : $369,1972$.
24）小倉貢, 觟村清司, 中村靖, 佐藤誠治, 岩下玲「女 子大学生の体力, 運功能力について」日本体育学会第 22回大会号 : 365, 1971 .

25）砂本秀義「ローレル指数よりみた体力運動能力」, 体育科教育, $17: 54-58,1969$.

26）竹内正堆, 山口晃「大学生の形热と運動能力に関す る研究 (II) 正課体育実技が体格・運動能力におよほ す影整について」星楽科大学紀要, $15: 30-36$, 1973.

27）田中英之, 金本哲夫, 久保玄次「女子大学生におけ る中学・高校時の運動部経医者と非運動部経験者との 運動能力の比較」日本体育学会第25回大会号：330, 1974.

28）徳永幹雄, 荒井貞光「体力低位学生の体育指竞四関 する研究一体力の变化炕関する資料と体力トレーニン グの実臨的武み一」九州大学体育学研究, 4:49$53,1972$.

29）德永幹雄, 桥本公雄「運動経臨と発育・発達に関す る研究一高校運動㟟手について一」日本体育学会第26 回大会号 : 438, 1975.

30）豊田博, 島津大宣, 遠藤郁夫「大学正課体育実技の 教育効果汇関する研究(3)体力, 特に敏唗性におよほす 影椑について」体育学紀要(東京大学教裳学部), 6 : 17-20, 1972.

31）八木保「体格及び体力の発育・発達と身体運動一遇 動歴による大学生の体格及び体力の差異一」体青学研 究, 16-1:25-33，1971.

32）横澤喜久子，鳥越成代，鈴木洋児，白鳥金丸「心拍 数変動加らみ大女子大生の身体活動第 1 報一正課体育 時の硬式テニスについて一」日本体育学会第26回大会 号 : 274, 1975.

33）篓田秀治「大学における正課および課外体育の体力 におよほす効果について」，体育学紀要 (東京大学教 学部), $5: 35-40,1971$. 